\title{
Ownership structure and the performance of firms: Evidence from France*
}

\author{
ÉRIC SÉVERIN ${ }^{1}$
}

\begin{abstract}
This paper deals with the influence of ownership structure, variables of external and organisational discipline on financial and economic performance. By means of self-organising maps, in particular Kohonen maps, we highlight three main results.

Firstly, the results obtained from a sample of French companies are consistent with the findings of Morck, Shleifer and Vishny (1988), McConnell and Servaes (1990) and Short and Keasey (1999) and suggest a non-linear relation between ownership structure and performance.

Secondly, the variables of external discipline, that is leverage and stock-turnover, partly explain performance. Although debt level negatively influences performance (Opler and Titman, 1994), conversely, stock-turnover has a beneficial impact on performance (Charreaux, 1997).

Finally, though the organisational variables seem to have no significant impact on performance, corporate size has a positive influence on performance.
\end{abstract}

Classification Codes: C450, G320.

\section{Introduction}

The numerous contributions concerning ownership structure show us the extreme richness on this topic over the last ten years. The financial literature has tried to measure the influence of ownership structure on corporate performance.

Currently three main hypotheses exist: the first is Jensen and Meckling's "convergence of interest" hypothesis in line with Berle and Means (1932); the second is the "neutrality hypothesis" and the third (Demsetz, 1983; Charrreaux, 1997) and last is the "entrenchment hypothesis" (Shleifer and Vishny, 1989). In agreement with these contributions

\footnotetext{
${ }^{1}$ Université de Lille 2, ESA-Laboratoire du Germe, 1 Place Déliot, BP 381, 59020 Lille Cedex.

E-mail: severin@hp-sc.univ-lille2.fr

* The author thanks Miss Celine Bernard for helping him improve in this article. He also acknowledges Éric de Bodt and the two anonymous referees for their comments.

Keywords: Ownership structure, performance, self-organising maps.
}

(c) EDP Sciences 2002 
Morck et al. (1988) or McConnell and Servaes (1990 and 1995) show that the relation between ownership structure and performance should be considered as non-linear.

The purpose of this article is to undertake an empirical analysis of the French context. Recognising that the association between ownership structure and performances appear confused, we will try to understand more clearly the "puzzle" of ownership structure. In other words, has the ownership structure-performance relationship a linear form (Berle and Means, 1932; Jensen and Meckling, 1976) or a non-linear form (Morck et al., 1988; McConnell and Servaes, 1990 and 1995; Short and Keasey, 1999)? If ownership structure partially explains corporate performance, can we find the reasons of performance in the organisational form, external discipline or size variables?

Several main results appear:

Firstly, our results suggest, using a sample of 199 French firms, that the relation between ownership structure and performance is non-linear. Our results are in line with the findings of Morck et al. (1988) and of Short and Keasey (1999).

Secondly, the two external discipline variables (that is leverage and the security turnover rate) partly explain performance. Although leverage negatively influences the performance (Opler and Titman, 1994) on the contrary security turnover rate has a beneficial impact on the performance (Charreaux, 1997).

Thirdly, though the organisational variables (Charreaux, 1997) do not have a meaningful impact on performance, size can explain differences between corporate performances.

This article is organized as follows. In Section 2 we discuss the relationship between ownership structure and corporate performance and we will present our working hypothesis. In Section 3 we describe our sample and our methodology. Our results are described in Section 4. Section 5 concludes.

\section{Theoretical discussion and working hypothesis}

\subsection{Ownership structure and performance: an unclear relationship}

According to the agency theory, several categories of shareholders can have an influence on the managers' efficiency: the managers-shareholders, the financial shareholders and the institutional shareholders. In the next part of our paper, we only focus on the managers-shareholders.

Now three main hypotheses exist to explain the relationship between ownership structure and performance. The first is Jensen and Meckling's "convergence in interest hypothesis". This theory in line with that of Berle and Means (1932) contending the greater the managerial ownership the less inclined the managers are to divert resources away from value maximisation. Consequently, the firm's performance increases uniformly. In contrast, Demsetz (1983) shows that corporate performance depends on environmental constraints. This hypothesis is known as the "neutrality hypothesis". For Demsetz (1983) all structures are equal. Finally the entrenchment hypothesis (Shleifer and Vishny, 1989) suggests that the greater the percentage of shares held by the manager, the less the other shareholders can compel him to manage the firm in their interests. In 
fact the managers may seek entrenchment by weakening the mechanisms able to control or replace them ${ }^{2}$ (Charreaux, 1997).

Numerous empirical studies have tried to highlight in evidence the relationship between ownership structure and corporate performance. The results are sometimes contradictory.

Some works showed a linear relation (Cole and Mehran, 1998) whereas other more recent studies highlighted a non-linear relation (Morck et al., 1988; McConnell and Servaes, 1990 and 1995; Kole, 1995; Short and Keasey, 1999).

Using Tobin's Q as a measurement of performance and the percentage of shares owned by the Board of Directors as a measure of ownership. Morck et al. (1988) used piecewise linear regression techniques (allowing the coefficients on the ownership variable to change at the $5 \%$ and $25 \%$ ownership levels) to estimate the relation between these variables. Their result suggested a positive relation between managerial ownership and Tobin's Q in the $0 \%$ to $5 \%$ range and beyond the $25 \%$ ownership level, although the magnitude of performance response to given changes in managerial ownership is substantially less beyond the $25 \%$ level. They also noticed a negative relationship in the $5 \%$ to $25 \%$ range. Morck et al. contend these results are consistent with the view that the convergence of interest effects is dominant within the $0 \%$ to $5 \%$ range and above the $25 \%$ level with the entrenchment effect being dominant within the $5 \%$ to $25 \%$ ownership range $^{3}$. In line with this paper McConnell and Servaes (1990) regressed Tobin's Q against managerial ownership and managerial ownership squared and found that the coefficient of management ownership was statistically significant and positive while the coefficient of managerial ownership squared was statistically significant and negative. The results suggest that the relationship between managerial ownership and the value of the firm is curvilinear. More accurately, the value of the firm increases and then decreases as ownership becomes concentrated in the hands of managers.

Specifically a positive relation between the performance of firms and managerial ownership exists for managerial ownership positions between $0 \%$ and approximately $40-50 \%$, which is consistent with incentive alignment occurring between ownership levels. These findings therefore differ from those of Morck et al. (1988) who found entrenchment to occur in the $5 \%$ to $25 \%$ ownership range. Moreover McConnell and Servaes were unable to replicate Morck et al.'s specific empirical findings using piecewise regression techniques. In addition McConnell and Servaes (1995) replicated their earlier study over a later time period and reported similar results.

In response to these different results, a recent paper by Kole (1995) suggests that the different findings of Morck et al. and McConnell and Servaes are attributable to

\footnotetext{
2 Jensen and Ruback (1983, pp. 5-50) show that takeovers play a disciplinary role. If managers are underperforming, they are sanctioned after the takeover. If the takeover succeeds, in most cases, the target's shareholders make profits whereas managers lose their jobs.

${ }^{3}$ It is important to note that the justification of thresholds chosen by Morck et al. (1988) is weak. This justification hinges on the SEC's reglementation that makes legal advertisement compulsory for interest higher than $5 \%$ and on the argument according to which, beyond $20-30 \%$, an aggressive take over bid can not succeed.
} 
differences in the size of firms analysed. Specifically, Morck et al. contained only large firms (371 firms from the Fortune 500) while McConnell and Servaes' sample consisted of 1173 firms in 1976 and 1093 firms in 1986. Hence the McConnell and Servaes' samples obviously contain firms which are smaller than those contained in the Morck et al. sample. Kole (1995, p. 426) argues that: "on average the positive relationship between Tobin's Q and the managerial ownership is sustained at higher levels of ownership for small firms than it is for large firms".

Other works have discussed all these results. To assess the impact of separation between ownership/decision on the performance, Demsetz and Lehn (1985) regress the rate profit accountant (for 511 American firms) against different measurements of shareholder concentration. They did not observe any statistically significant relation between the rate of profitability of equity and an indicator of capital diffusion. Finally Charreaux (1997), in an empirical study of 106 listed French firms, argued for "non-linearity presumption" in line with the results of Morck et al. (1988) and Demsetz and Lehn (1985).

\subsection{Working Hypothesis}

From these different contributions several elements appear:

Firstly, the relation between structure of property and performance ${ }^{4}$ appears to be unclear. Among all the empirical contributions, no thesis really seems to dominate.

Secondly, authors do not use the same measurements to value ownership structure (and in particular managerial ownership). Morck et al. (1988) defined managerial ownership as ownership held by members of Board of Directors. It does however differ from McConnell and Servaes (1990) who defined management ownership as equity owned by corporate officers and members of the Board of Directors.

Thirdly, measurements of performances as underlined by Charreaux (1997) deserve greater precision. A distinction must be made between book and market value, between ex-ante and ex-post measurement and finally shareholder and total value.

Fourthly, most studies recognise that the chosen percentages to determine the structure of the capital remain imperfect. Indeed the percentage owned by shareholders is not still identical to voting rights (action with double voting rights for example).

Thus, one can estimate that the role of managers in the value growth of the firm appears ambiguous.

Even if we are conscious that performance is also dependent upon many factors (external or internal: debt, industrial sector, economic cycle...), it is obvious that it is very difficult to take into account all of these factors. In this paper we wish to understand the influence of ownership structure on corporate performance.

In line with Morck et al. (1988) or McConnell and Servaes (1990 and 1995) or again Short and Keasey (1999), all of these investigations allowed us to make the following assumption: the relation between managerial ownership and performance is non-linear.

\footnotetext{
${ }^{4}$ We are aware that the performance is also dependent upon debt (Jensen, 1986), industrial sector (Opler and Titman, 1994), economic cycle (Platt and Platt, 1994), or the management's reputation (Pigé, 1997). In this paper, we focus only on managerial and ownership structure.
} 
Can we observe this phenomenon in practice? In other words, does managerial structure influence corporate performance positively or negatively?

If so, can we determine the causes for the different equilibriums? In this framework, we will find the variables able to explain corporate performance. As these variables are numerous, we will focus in particular on external discipline or organisational variables.

\section{Data and Methodology}

\subsection{Sample}

The sample was chosen from French firms listed on the Paris Bourse in $1996^{5}$. We were careful to neutralize the effects of increases in capital, of splits and of free equity distributions. After applying these criteria 456 firms were retained.

Moreover, we used data from Dafsa-Pro ${ }^{6}$ in $1996^{7}$ but excluded:

- firms in the financial sector (the accounting treatment of profit for these firms is significantly different than that of other sectors);

- firms for which the required data was unavailable.

After applying these subsequent criteria 199 firms were retained for our empirical analysis $^{8}$.

We used the following information from the database: total assets, equity, financial debt, total debt, sales, total of interests and profits.

With the classification of the $\mathrm{SBF}^{9}$, we carried out classification per sector. This classification is presented in Table 1. This table distinguishes industrial sector and services sector.

TABLE 1. Number of firms in industrial and services sectors in the 1995-1996 period.

\begin{tabular}{|l|c|c|}
\hline Sector & Sub-Sectors & $\begin{array}{c}\text { Number } \\
\text { of firms }\end{array}$ \\
\hline Industrial Sector & $\begin{array}{c}\text { Energy, Basic Commodities, Construction, } \\
\text { Consumer Goods, Car Industry, Other } \\
\text { Consumer Goods, Food Industry }\end{array}$ & 138 \\
\hline Services Sector & Distribution, Other Services & 61 \\
\hline Total & & 199 \\
\hline
\end{tabular}

\footnotetext{
5 The sample includes firms listed on the "Règlement Mensuel", the "Comptant" and the "Second Marché".

${ }^{6}$ We have used the data issued from Dafsa Pro. In France, most companies within Dafsa Pro provide complete annual reports. Dafsa Pro delivers this data on CD-ROM.

${ }^{7}$ This data set is available from the Lille Stock Market.

${ }^{8}$ The validity of accounting data has been validated by using series of tests of coherence. These tests of coherence concern about the errors or unavailable data.

${ }^{9} \mathrm{SBF}$ is a data set in which a sectorial classification is given.
} 
Several remarks may be made. On the one hand our sample has a predominance of industrial firms $(70 \%)$ compared to those in the service sector (30\%) - all firms in the financial and banking sectors were excluded-. On the other hand it is important to note that within the whole population, the percentages of firms in industrial and services sectors are respectively $67 \%$ and $33 \%$. With a Chi-square test, we report no statistically significant difference. Finally, it is important to note that the (Other services) sector is not homogeneous. Indeed, in this sector, we can find firms in communication, tourism, computers etc.

From this sample we collected data of ownership structure for 1995. In particular: ownership structure, the composition of the Board of Directors, the percentage of equity owned by the Board of Directors.

\subsection{Pertinence of Measurements in Performance and Ownership structure}

As we sought to highlight the relationship between ownership structure and performance, we chose two types of indicators for these two measurements.

\subsubsection{ROI, ROE, Tobin's $Q$ and Marris: Indicators of performance}

Although the performance is a fundamental element of the financial literature, its measure is more problematic. As underlined by Charreaux (1997, p. 32): "An adequate performance measurement should be able to give into account all the consequence on the wealth of stakeholders". Nevertheless the choice of a performance measurement is complex for several reasons. Indeed it will differ depending on the shareholder or stakeholder value maximisation. The former is interested in the shareholder because he is the owner of the firm. The latter considers that economic performance is to the key element because it is the origin of global (or stakeholder) value ${ }^{10}$. Regardless of this distinction, Charreaux (1997, pp. 63-64) underlined that another separation can be introduced between ex-ante and ex-post performance. So the Marris ratio (Market value of equity/ book value of equity) and Tobin's $Q$ (market value of assets/replacement value of assets) are calculated in market value. These last two values are dependent on the anticipations of investors. On the other hand, ROI and ROE are ex-post indicators because rates of profitability are calculated ex-post.

Table 2 gives a summary of this discussion.

TABLE 2. Indicators of performance.

\begin{tabular}{|l|l|l|}
\hline Indicator & Book value & Market value \\
\hline Economic profitability & ROI (ex-post) & Q (ex-ante) \\
\hline Financial profitability & ROE (ex-post) & Marris (ex-ante) \\
\hline
\end{tabular}

\footnotetext{
${ }^{10}$ The link between economic (stakeholders' interests) and financial (shareholders' interests) performance lies in the leverage effect. The leverage represents the influence of financial structure on the corporate performance.
} 
ROI values the total performance of the firm. ROI is calculated in book value and equals to: (net result + interes $^{11}$ ) / (equity + total debt). This conception that we will follow implies that the corresponding output to amounts of vested interests includes the net result returned to shareholders and the financial costs of paying creditors at that time. Nevertheless this indicator is not free of criticism. Indeed ROI uses the net profit that very often includes non-operating elements. That is why it would be better to choose EBITDA (earning before interest and taxes and depreciation) because this measurement excludes in particular amortisation. In spite of these imperfections and to simplify, we will choose the final net result.

Financial performance is given by the ROE (net profit / equity - in book value -). This indicator is very important for shareholders. However the ROE does not permit assessment of the profitability of all invested funds. Furthermore, we were careful to reprocess the absurd values ${ }^{12}$.

Tobin's Q (market value of assets / replacement value of assets) is traditionally used in the financial literature (Lang and Litzenberger, 1989; Howe et al., 1992; Denis, Denis and Sarin, 1994). Lang and Litzenberger (1989) justify the utilisation of Tobin's Q as measurement of growth opportunities. They show that a Tobin's $Q$ above 1 is a necessary condition for a firm to be at a level of investment that maximises its value and that a Tobin's Q below 1 characterises a firm with no growth opportunities. In France, we cannot strictly use this measurement because some items ${ }^{13}$ (for instance debt maturity, market value of the debt, interest rates or value replacement of the firm) are not available in our dataset. Hence we chose the total assets instead of the replacement value. Thus the measurement of Tobin's $\mathrm{Q}$ is the ratio becomes (market value of equity + book value of debt/total of assets - in book value -$)^{14}$.

The Marris ratio (market value of equity / book value of equity) is an indicator of growth opportunities. As specified by Hirigoyen and Caby (1997, pp. 18-19), the Marris ratio "is a permanent valuation indicator of choices of the firm, of the management and of strategic perspectives". When this ratio is higher than 1 the firm creates value. In a contrary situation, it destroys value.

\subsubsection{Ownership variables}

In line with Morck et al. (1988) and by assuming that the relation between performance and ownership structure is non-linear, we define managerial ownership as ownership by members of Board of Directors (BOD). Considering that the utilisation of American levels is not possible, we have chosen the following levels: $33 \%, 50 \%$ and $66 \%$.

Our justification of these strategic levels is described in Table 3 .

\footnotetext{
${ }^{11}$ We measured the ratio interests divided by total of financial debt and we noted no absurd value (that is to say value outside the market conditions).

${ }^{12}$ In particular, we checked if the equity value was always positive. All values were positive.

${ }^{13}$ Lang and Litzenberger (1989) chose the debt in book value when the market value was not available.

${ }^{14}$ This measurement was chosen by Nijoukou (1994), Noronha et al. (1996).
} 
TABLE 3. Percentage of capital owned by the Boards of Directors.

\begin{tabular}{|l|c|}
\hline Equity held & Comments \\
\hline $\mathrm{CO}<33 \%$ & Insufficient minority \\
\hline $33 \%<\mathrm{CO}<50 \%$ & Minority vote \\
\hline $50 \%<\mathrm{CO}<66 \%$ & Simple Majority \\
\hline $66 \%<\mathrm{CO}$ & Absolute Majority \\
\hline
\end{tabular}

With this first measurement, we also used another recommended by Charreaux (1997), determined by the main features of the firm (family firms, controlled firms and managerial firms, see Charreaux, 1991) ${ }^{15}$.

\subsubsection{External discipline, organisational and size variables}

\section{External discipline variables}

Nevertheless as specified by Charreaux (1997), if we wish to understand whether the managerial ownership really has an influence on the performance, it is necessary to be able to take into account the impact of external variables (discipline by the market) and organisational variables.

We will use two variables of external disciplines: security turnover rate and leverage.

The reason for choosing the security turnover rate (STR) is in line with the arguments of Titman and Wessels (1988). These authors indicate that a considerable volume of transactions shows the discipline of the financial market. It is a means of putting pressure on management to act in accordance with interests of investors.

The financial structure is also able to reduce agency conflicts and to reduce free cash flow (Jensen, 1986). We measured this indicator in three ways. In line with Charreaux (1997) we chose to measure leverage by the ratio of book value of financial debt divided by the total of equity in book value (FIDEEQUI -BV-) and by the ratio of book ratio of financial debt divided by the total of equity in market value (FIDEEQUI -MV-). Finally, we used also in line with Short and Keasey (1999) the ratio of book value of financial debt divided by the total of assets in book value (TDTA).

\section{Organisational variables}

Several variables may be chosen (Charreaux, 1997). In fact, we used the percentage of outside directors, because it measures the intensity of the control by the Board of

\footnotetext{
${ }^{15} \mathrm{~A}$ firm is said to be controlled if it capital is held by another company, with a minimum of $50 \%$ or a minimum of $30 \%$ should no other shareholder have more than $10 \%$ of the capital. The controlled firms also extensively include those for which a majority of capital is held by 3 reference shareholding companies. The "family-firms" are those for which the previous thresholds have been retained, in the knowledge that here this indicates the presence of a family or an identifiable individual person. Managerial firms are those not classified in other categories.
} 
Directors (OUTDIR). Our choice is in line with Fama (1980) who indicated that it must have a beneficial influence on performance, in particular in managerial firms.

\section{Size variable}

Furthermore, we used another control variable: size defined by the logarithm of the total assets (LNTA).

Variables are described in Table 4:

TABLE 4. Variables Description.

\begin{tabular}{|c|c|}
\hline Variables & Description \\
\hline \multicolumn{2}{|c|}{ Performance Variables } \\
\hline Tobin's Q & (Market value of equity + book value of debt) / (Total of assets in book value) \\
\hline Marris & (Market value of equity) / (Book value of equity) \\
\hline ROI & (Net result + interests in book value) $/$ (Equity + total debt in book value) \\
\hline ROE & (Net profit) / (Equity in book value) \\
\hline \multicolumn{2}{|c|}{ Ownership structure variables } \\
\hline BOD & $\%$ held by the Board of Directors \\
\hline \multicolumn{2}{|c|}{ External discipline variables } \\
\hline STR & Security turnover rate \\
\hline $\begin{array}{l}\text { FIDEEQUI (BV) } \\
\text { FIDEEQUI (MV) } \\
\text { TDTA }\end{array}$ & $\begin{array}{c}\text { (Financial debt in book value) / (Total of Equity in book value) } \\
\text { (Financial debt in book value)/ (Total of Equity in market value) } \\
\text { (Total debt in book value) / (Total assets in book value) }\end{array}$ \\
\hline \multicolumn{2}{|c|}{ Organizational variables } \\
\hline OUTDIR & Outside directors \\
\hline \multicolumn{2}{|l|}{ Size variable } \\
\hline LNTA & Log (Total assets) \\
\hline
\end{tabular}

Finally let us note that like John and Ofek (1995), all our variables of performance have been industry-adjusted by the sectorial median. The median is an indicator of central value of a distribution and it is better than the average because the influence of extreme value is less important.

\subsection{Methodology: Data Analysis and KACM ${ }^{16}$}

By assuming that, firstly, no consensus exists on the influence of ownership structure on performance and secondly, it may exist a non-linear relationship between ownership structure and corporate performance (Morck et al., 1988; McConnell and Servaes, 1990;

\footnotetext{
${ }^{16}$ See Ibbou (1998). The KACM analysis allows to classify Q qualitative data when Q is superior to 2. Some recent applications can be noticed (Gaubert et Cottrell, 1999 and 2000).
} 
Short and Keasey, 1999), we focused our attention on self-organized maps (SOM) and more especially on one of the variants called the Kohonen Map (Kohonen, 1982 and 1995). One of the major advantages in its use is its capacity to deal with non-linear problems in particular.

Our objective was to determine several groups of homogeneous individuals. Secondly, we used non-parametric tests (Wilcoxon and $\chi^{2}$ ) to highlight significant differences between our groups.

Many traditional ${ }^{17}$ methods presuppose strong hypotheses: in particular, the assumption of normality. To test this, we examined the distribution of the ratios. Using the Kolmogorov test (App. 1) could test normality. This appendix shows that our ratios do not have a normal distribution and that there are extreme values that require the use of qualitative data. This non-normality and the presence of extreme values led us to cluster our individuals into 4 classes. Hence, we first transformed each $X_{i}$ character (that is to say the performance variables: Tobin's Q, Marris, ROI, ROE and the ownership structure variable: BOD) into 4 categories (very strong, strong, weak, very weak ${ }^{18}$ ) and secondly transformed our variables into binary variables. The table of value of $X$ turn into a table of $N$ rows (in our cases the 199 individuals) and 20 columns corresponding to 20 qualitative data (each variable has 4 categories).

We clustered the sample with our variables of leverage and performance. This technique allows the relationship between the different variables to be observed. However, the findings (App. 2) were not satisfactory. The total inertia shown was weak (30\%) and we could not distinguish groups of homogenous individuals. For this reason, we used the Kohonen algorithm because of its capacity to solve non-linear problems.

Thus we used a specific kind of self-organized map (SOM) called the Kohonen map $^{19,20}$. The Kohonen algorithm ${ }^{21}$ is a well-known unsupervised learning algorithm that produces a map composed of a fixed number of units (Fig. 1 presents a one-dimensional map, frequently called a string). Each unit has a specific position on the map and is associated with an $n$-dimensional vector $W_{i}$ (which will define its position in the

\footnotetext{
${ }^{17}$ Traditional methods use multidimensional analysis. This type of analysis aims at a structuring of studied sample in relation to the measured variables. Thus, we can visualise the existing relations between statistical variables (Saporta, 1990). If we apply this method to qualitative variables, we realise a MCA (Multiple Component Analysis, see Volle, 1981).

${ }^{18}$ We divided the sample into four classes of equal size for performance. For ownership structure, we divided the sample into four classes that is to say: if the percentage owned by the Board of Directors was over to $66 \%$, we noted BODVS, for a percentage owned between $50 \%$ and $66 \%$, we noted BODS, for a percentage owned between $33 \%$ and $50 \%$, we noted BODW, and for a percentage below to $33 \%$, we noted BODVW.

${ }^{19}$ An extensive presentation can be found in Kohonen (1982, p. 59) or in Kohonen (1995).

${ }^{20}$ Kohonen maps have been used in many applications (Kohonen himself refers to more than 1500 applications in his book (1995).

${ }^{21}$ The Kohonen algorithm led to some theoretical studies (Cottrell et al., 1987, pp. 1-20; Cottrell et al., 1994; Ritter and Schulten, 1988, pp. 59-71), and to interesting applications in economics (and more specifically in finance). The self organised map (SOM) deals with quantitative data. In our paper we have adopted them to qualitative data.
} 
input space); $n$ being the number of dimensions of the input space. Moreover, a physical neighborhood relation between the units is defined (Fig. 1). Units 1 and 3 are neighbors of Unit 2 and for each unit $i . \operatorname{Vr}(i)$ represents the neighborhood with the radius $r$ centered at $i$.

After learning, each unit represents a group of individuals with similar features. The correspondence between the individuals and the units more or less respects the input space topology: individuals with similar features correspond to the same unit or to neighboring units. The final map is said to be a self-organized map that preserves the topology of the input space.

The learning algorithm takes the following form:

- at time $0 . W_{i}(0)$ is randomly defined for each unit $i$,

- at time $t$ we present a vector $x(t)$ randomly chosen according to the input density $f$ and we determine the winning unit $i^{*}$ which minimizes the Euclidean distance between $x(t)$ and $W_{i}(t)$. We then modify the $W_{i}$ in order to move the weights of the winning unit $i^{*}$ and its physical neighbors towards $x(t)$ using the following relations:

$$
\begin{gathered}
W_{i}(t+1)=W_{i}(t)+\left[\varepsilon(t) \times\left(x(t)-W_{i}(t)\right)\right] \text { for } i \in V_{r(t)}\left(i^{*}\right) \\
W_{i}(t+1)=W_{i}(t) \text { for other } i
\end{gathered}
$$

where $\varepsilon(t)$ is a small positive adaptation parameter, $r(t)$ is the radius of $\operatorname{Vr}(t)$ and $\varepsilon(t)$ and $r(t)$ are progressively decreased during the learning ${ }^{22}$.

This is clearly a competitive kind of algorithm (each unit competes to be the closest to the presented individual) which will perform two interesting tasks for data analysis:

1) clustering ${ }^{23}$ : each unit will be associated with a similar kind of individual. the $W_{i}$ vector associated with the unit converging toward the mean profile of the associated individuals;

2) reduction in the number of dimensions: the (at least local) proximities between the units will give us an idea of the proximities of clusters of individuals in the input space.

A last remark concerning the neighborhood: it is reduced progressively to finish at value 0 (only the winning unit is displaced). The Kohonen algorithm then turns into a vectorial quantification.

To assess the statistical significance of the results obtained with the Kohonen map. We used traditional tests (Wilcoxon ${ }^{24}$ and chi-square ${ }^{25}$ ).

\footnotetext{
${ }^{22}$ For the stochastic algorithm $\varepsilon(t)$ must follow the requirements of Robins-Monro.

${ }^{23}$ Moreover, the quality of the clustering can easily be supervised by the analysis of ratios like "Inter Cluster Sum of Squares" (SSInter) on "Total Sum of Squares"(SSTotal) as would have been done with classical data analysis tools.

${ }^{24}$ It is a rank test. Its justification is due to the non-normality of data. Tests of ranks are very robust. By arranging the different observations (i.e. by giving them a rank), one identifies the place of every observation in the sample. One substitutes rank for observation. Thus one neutralises problems concerning the accurate measurement of the value for every observation. We can also note that the results of rank tests are not altered by the distributions of observations (symmetrical, non-symmetrical...).

${ }^{25}$ The $\chi^{2}$ test is a test of independence that serves to determine if samples come from the same population.
} 


\section{Results}

\subsection{The Non-Linear Relationship Between Ownership Structure and Performance}

Many methods have been used to represent the Kohonen map in order to facilitate the analysis of the underlying data set (App. 3). A good synthesis is also provided in Kohonen (1995) and Deboeck and Kohonen (1998, pp. 2-38). In this study, we used one representation to plot the Kohonen grid (or string) on a plane, each unit having the same size. It is the classical Kohonen map representation.

\begin{tabular}{|l|l|l|l|}
\hline (Unit 1) & \multicolumn{1}{l}{ (Unit 2) } & \multicolumn{1}{l|}{ (Unit 3) } & (Unit 4) \\
\hline ROIVS & ROIS & ROIW & ROIVW \\
ROEVS & ROES & ROEW & ROEVW \\
QVS & QS & QW & QVW \\
MVS & MS & MW & MVW \\
BODS & BODW & BODVW & BODVS \\
\hline
\end{tabular}

ROIVS, ROIFS, ROIFW, ROITVW: ROI very strong, strong, weak, very weak. ROEVS, ROES, ROEW, ROEVW: ROE very strong, strong, weak, very weak. QVS, QS, QW, QVW: Tobin's Q very strong, strong, weak, very weak. MVS, MS, MW, MVW: Marris very strong, strong, weak, very weak. BODVS, BODS, BODW, BODVW: \% of capital held by the Board of Directors very strong (BOD $>66 \%)$, strong $(50 \%<\mathrm{BOD}<66 \%)$, weak $(33 \%<\mathrm{BOD}$ $<50 \%$ ), very weak $(\mathrm{BOD}<33 \%)$.

Fig. 1. Representation by the Kohonen map of the relation between the ownership structure (measured by the percentage of capital held by the Boards of Directors) and the performance.

The representation of the Kohonen map highlights that all performance variables converge. It is important to note that firms with the worst performances are those where the percentage detained by the management is the greater. Nevertheless, the influence of ownership structure on corporate performance seems complex. The coexistence of positive and negative effects of ownership structure on performance leads us to note that the relationship between ownership structure and performance is non-linear. Our working hypothesis is verified. Our results are in line with those of McConnell and Servaes (1990) showing firstly that performance increases and afterwards decreases when the shares are concentrated in the hands of managers. In the extension of their interpretation we cannot explain the negative relationship between ownership structure and corporate performance when ownership becomes highly concentrated in the hands of managers ${ }^{26}$.

\footnotetext{
${ }^{26}$ McConnell and Servaes (1990, p. 611) underline it in the following sentence : "This line of reasoning cannot explain the observed negative relation between ownership and Q that occurs as ownership becomes highly concentrated in the hands of insiders".
} 
More precisely, the Kohonen map (Fig. 1) shows us that between 0 and $66 \%$ the "convergence in interest hypothesis" is verified, then when the percentage held the administrators is above $66 \%$, there are conflicts of interests between managers and shareholders.

Consequently, we attempted to determine the characteristics of the individuals located in each unit of the Kohonen map. The second work consists in working on the individuals. After learning, we obtained 36 individuals in Unit 1; 70 in Unit 2; 59 in Unit 3; and 34 in Unit 4 (see Ibbou, 1998).

\subsection{A non parametric test of ownership variables}

Charreaux (1991) classified the French firms into three categories: family, controlled and managerial firms. In support of this typology Charreaux (1997) observed that although the ownership structure has no influence on financial performance, it does however seem to have an influence on economic performance especially for family firms. In line with this result, we will try to determine if ownership structure has an influence on performance by using the $\chi^{2}$ test.

TABLE 5. Description and comparison of firms located in Units 1 and 4 ( $\%$ held by the Board of Directors).

\begin{tabular}{|l|c|c|}
\hline & $\begin{array}{c}\text { Firms with very strong } \\
\text { performance (Unit 1) }\end{array}$ & $\begin{array}{c}\text { Firms with very weak } \\
\text { performance (Unit 4) }\end{array}$ \\
\hline Family firms & 6 & 10 \\
\hline Managerial firms & 5 & 18 \\
\hline Controlled firms & 25 & $\chi^{2}=1.89$ \\
\hline & & \multicolumn{2}{|c|}{} \\
\hline
\end{tabular}

TABLE 6. Description and comparison between firms located in Units 1 and 2 and firms located in Units 3 and 4 (\% held by the Board of Directors).

\begin{tabular}{|l|c|c|}
\hline & $\begin{array}{c}\text { Firms with strong and very strong } \\
\text { performance (Units 1 and 2) }\end{array}$ & $\begin{array}{c}\text { Firms with weak and very weak } \\
\text { performance (Units 3 and 4) }\end{array}$ \\
\hline Family firms & 23 & 25 \\
\hline Managerial firms & 19 & 20 \\
\hline Controlled firms & 64 & 48 \\
\hline & & $\chi^{2}=1.38$ \\
\hline
\end{tabular}

The results in Tables 5 and 6 show us that no result is statistically significant. Our results are in line with those of Charreaux (1997). In fact the ownership structure has no (or very little) influence on performance. 


\subsection{A non parametric test of the external discipline variables, the organisational variables and the size variable}

If there is a "neutrality" ownership structure on performance, we would like to know the impacts of external discipline variables, of organisational variables and the size variable on performance.

TABLE 7. Descriptive Statistics of discipline and external variables of Units 1, 2, 3 and 4.

\begin{tabular}{|c|c|c|c|c|c|}
\hline & & TDTA & FIDEEQUI (BV) & FIDEEQUI (MV) & STR \\
\hline Unit 1 & $N$ & 36 & 36 & 36 & 36 \\
\hline \multirow{2}{*}{ Very effective firms } & Mean & 0.509 & 0.795 & 0.736 & 29.523 \\
\cline { 2 - 6 } & Median & 0.517 & 0.401 & 0.156 & 28.670 \\
\hline Unit 2 & $N$ & 70 & 70 & 70 & 70 \\
\hline \multirow{2}{*}{ Effective firms } & Mean & 0.530 & 0.780 & 0.596 & 27.522 \\
\cline { 2 - 6 } & Median & 0.534 & 0.464 & 0.324 & 21.791 \\
\hline Unit 3 & $N$ & 59 & 59 & 59 & 59 \\
\hline \multirow{2}{*}{ Firms with poor performance } & Mean & 0.562 & 0.953 & 0.820 & 25.338 \\
\cline { 2 - 6 } & Median & 0.571 & 0.767 & 0.636 & 19.480 \\
\hline Unit 4 & $N$ & 34 & 34 & 34 & 34 \\
\hline \multirow{2}{*}{ Firms with very poor performance } & Mean & 0.561 & 0.911 & 1.135 & 14.810 \\
\cline { 2 - 6 } & Median & 0.568 & 0.639 & 1.025 & 8.700 \\
\hline Total & $N$ & 199 & 199 & 199 & 199 \\
\hline \multirow{2}{*}{$\begin{array}{c}* \\
\text { N }\end{array}$} & Mean & 0.541 & 0.856 & 0.782 & 27.117 \\
\hline
\end{tabular}

Note: Debt has been measured at the end of 1995, the security turnover rate has been measured in 1996 (in thousands of titles). $N=$ Number of observations.

TABLE 8. The Wilcoxon test of external and discipline variables between very effective firms and firms with very poor performance.

\begin{tabular}{|l|c|c|}
\hline Variables & \multicolumn{2}{|c|}{ Unit $1 v s$. unit 4} \\
\hline & Ownership structure: \% held by the Board of Directors \\
\hline & Wilcoxon statistic & $p$ value \\
\hline TDTA & -1.311 & 0.190 \\
\hline FIDEEQUI(BV) & -1.645 & $0.100^{*}$ \\
\hline FIDEEQUI(MV) & -3.818 & $0.000^{* * *}$ \\
\hline STR & -3.933 & $0.000^{* * *}$ \\
\hline
\end{tabular}

Note: $* * * * *$ and $*$ significant at the 1,5 et $10 \%$ threshold. 
Tables 7 and 8 give some important results to comment. First of all, the results indicate that the effective businesses have security turnover rate statistically different (at the $1 \%$ threshold). Our results are in line with those of Charreaux (1997).

Secondly, leverage seemed to have a negative influence on performance (in particular when we used the ratio of financial debt -in book value- divided by the total of equity in market value - (a statistically significant result at the $1 \%$ threshold) or by using the ratio financial debt - in book value - divided by the total of equity - in book value (a statistically significant result at the $10 \%$ threshold). Hence leverage had a negative influence on performance. This result is in line with Opler and Titman (1994) but is not consistent with the "free cash flow hypothesis" of Jensen (1986) which explains that the best way to reduce conflicts of interest is to increase the debt level. Leverage provides discipline and monitoring not available to a firm completely financed by equity. According to the "free cash flow" theory, debt creates value by imposing discipline on organizations, which in turn reduces agency costs (Jensen, 1986). The use of debt has two functions: 1) it decreases the free cash flow that can be wasted by managers and, 2 ) it increases the probability of bankruptcy and the possibility of job loss for managers ${ }^{27}$ (thus leading to the disciplining effect).

TABLE 9. Descriptive statistics of organisational and size variables for Units 1, 2, 3 and 4 (Percentage held by the Board of Directors).

\begin{tabular}{|c|c|c|c|}
\hline & & LNTA & OUTDIR \\
\hline Unit 1 & $N$ & 36 & 36 \\
\hline \multirow{2}{*}{ Very effective firms } & Mean & 14.727 & 0.728 \\
\cline { 2 - 4 } & Median & 14.840 & 0.750 \\
\hline Unit 2 & $N$ & 70 & 70 \\
\hline \multirow{2}{*}{ Effective firms } & Mean & 14.863 & 0.752 \\
\cline { 2 - 4 } & Median & 14.410 & 0.773 \\
\hline Unit 3 & $N$ & 59 & 59 \\
\hline \multirow{2}{*}{ Firms with poor performance } & Mean & 14.747 & 0.775 \\
\cline { 2 - 4 } & Median & 14.264 & 0.775 \\
\hline Unit 4 & $N$ & 34 & 34 \\
\hline \multirow{2}{*}{ Firms with very poor performance } & Mean & 13.871 & 0.788 \\
\cline { 2 - 4 } & Median & 13.234 & 0.818 \\
\hline Total & $N$ & 199 & 199 \\
\hline & Mean & 14.640 & 0.761 \\
\hline & Median & 14.204 & 0.800 \\
\hline
\end{tabular}

Note: $\mathrm{LNTA}=\log ($ Total assets $)$, OUTDIR $=\%$ outside directors, $N=$ Number of observations.

\footnotetext{
${ }^{27}$ Jensen (1986, pp. 323-329) defines free cash flow as the cash available when all projects with NPV $>0$ have been realized.
} 
TABLE 10. The Wilcoxon test on organisational and size variables between very effective firms and firms with the poor performance.

\begin{tabular}{|l|c|c|}
\hline Variables & \multicolumn{2}{|c|}{ Unit 1 vs. unit 4} \\
\hline & Ownership structure: \% held by the Board of Directors \\
\hline & Wilcoxon statistic & $p$ value \\
\hline LNTA & -2.427 & $0.015^{* *}$ \\
\hline OUTDIR & -1.118 & 0.263 \\
\hline
\end{tabular}

Note: $* * *, * *$ and $*$ significant at the 1,5 et $10 \%$ threshold.

Tables 9 and 10 suggest that size was a positive influence on performance. This result is in line with Short and Keasey (1999) on the English market. But, the impact of outside directors cannot give a definite conclusion. In fact, the role of outside directors in financial the literature is ambiguous. On the one hand, as underlined by Eisenhardt and Bourgeois (1988) or Kosnik (1990), their independence leads them to consider the managers' decisions with distance (which is an advantage). On the other hand, their impartiality can be debateable (Mace, 1986; Vancil, 1987; Waldo, 1985) because their recruiting process is dominated by the CEO. Moreover the percentage of shares held by the outside directors is generally low (Mace, 1986; Patton and Baker, 1987; Jensen, 1993), which does not incite them to act in accordance with the interests of shareholders.

\subsection{Multivariate Analysis}

In order to understand more clearly the role of the external and organisational variables on the corporate performance more clearly, we carried out an empirical analysis by using a piecewise linear regression with the following form ${ }^{28}$ :

Performance $=$ Intercept $+B 1(L N T A)+B 2(S \mathrm{TR})+B 3(S \mathrm{TR} \times G 2)+B 4(S \mathrm{TR} \times G 3)$

$+B 5(S \mathrm{TR} \times G 4)+B 6($ FIDEEQUI $(M V))+B 7($ FIDEEQUI $(M V) \times G 2)$

$+B 8($ FIDEEQUI $(M V) \times G 3)+B 9($ FIDEEQUI $(M V) \times G 4)+\varepsilon$

with:

Performance $=$ ROI, ROE, Tobin's Q, Marris

LNTA $=$ Log (Total assets)

FIDEEQUI(MV) = Financial debt in book value/Total of Equity in market value

$\mathrm{G} 2=$ dummy variable $=1$ if the firm belongs to Unit 2, 0 otherwise

$\mathrm{G} 3=$ dummy variable $=1$ if the firm belongs to Unit 3, 0 otherwise

$\mathrm{G} 4=$ dummy variable $=1$ if the firm belongs to Unit 4,0 otherwise

To regress, we tested the extreme value in order to avoid the bias generated by these extreme values ${ }^{29}$.

\footnotetext{
${ }^{28}$ A very good synthesis is presented by Gujarati (1995, pp. 499-539).

${ }^{29}$ In all the performed regressions, we restricted the number of variables to be explained so as to get quasinormal distributions. On the other hand, we were careful to verify the autocorrelation (Durbin-Watson test) and their heteroskedasticity (White test). None of these tests provided statistically significant results.
} 
TABLE 11. Estimation of coefficients of (3). To regress, we used as measurement of leverage, the ratio financial debt in book value divided by total of equity (in market value). The choice of taking the equity in market value is due to very statistically significant differences (at the $1 \%$ threshold) between the units. The performance and leverage variables are all industry-adjusted. Student- $T$ values are in brackets.

\begin{tabular}{|c|c|c|c|c|}
\hline & ROI & ROE & Tobin’s Q & Marris \\
\hline \multirow[t]{2}{*}{ Constant } & 0.0187 & -0.064 & -0.029 & -0.909 \\
\hline & $(0.7449)$ & $(-1.148)$ & $(-0.154)$ & $(-2.483)^{* *}$ \\
\hline \multirow[t]{2}{*}{ LNTA } & 0.0015 & 0.003 & 0.013 & 0.076 \\
\hline & $(0.8085)$ & $(0.660)$ & $(0.948)$ & $(2.844)^{* * *}$ \\
\hline \multirow[t]{2}{*}{ STR } & 0.0006 & 0.002 & 0.012 & 0.024 \\
\hline & $(2.3439)^{* *}$ & $(2.923)^{* * *}$ & $(6.064)^{* * *}$ & $(6.488)^{* * *}$ \\
\hline \multirow[t]{2}{*}{ STRG2 } & -0.0004 & -0.001 & -0.009 & -0.019 \\
\hline & $(-1.4389)$ & $(-1.788)^{*}$ & $(-5.079) * * *$ & $(-5.399) * * *$ \\
\hline \multirow[t]{2}{*}{ STRG3 } & -0.0004 & -0.001 & -0.014 & -0.028 \\
\hline & $(-1.4879)$ & $(-1.620)$ & $(-6.613)^{* * *}$ & $(-6.649) * * *$ \\
\hline \multirow[t]{2}{*}{ STRG4 } & -0.0005 & -0.001 & -0.016 & -0.037 \\
\hline & $(-1.1610)$ & $(-1.145)$ & $(-4.942)^{* * *}$ & $(-5.778) * * *$ \\
\hline \multirow[t]{2}{*}{ FIDEEQUI (MV) } & -0.0022 & -0.0003 & -0.037 & -0.063 \\
\hline & $(-0.5776)$ & $(-0.037)$ & $(-1.277)$ & $(-1.126)$ \\
\hline \multirow[t]{2}{*}{ FIDEEQUI (MV) G2 } & -0.0098 & -0.018 & -0.118 & -0.035 \\
\hline & $(-1.3244)$ & $(-1.110)$ & $(-2.107)^{* *}$ & $(-0.321)$ \\
\hline \multirow[t]{2}{*}{ FIDEEQUI (MV) G3 } & -0.0151 & -0.040 & -0.109 & -0.185 \\
\hline & $(-1.9534)^{*}$ & $(-2.315)^{* *}$ & $(-1.864)^{*}$ & $(-1.637)^{*}$ \\
\hline \multirow[t]{2}{*}{ FIDEEQUI (MV) G4 } & -0.0138 & -0.055 & -0.137 & -0.297 \\
\hline & $(-1.9143)^{*}$ & $(-3.375) * * *$ & $(-2.502)^{* *}$ & $(-2.805) * * *$ \\
\hline $\mathrm{F}$ & $2.49 *$ & $6.04 * * *$ & $15.35 * * *$ & $18.62 * * *$ \\
\hline $\mathrm{R} 2$ & 10.6 & 18.6 & 32.4 & 44.4 \\
\hline
\end{tabular}

Note: $* * *, * *$ and $*$ significant at the 1,5 et $10 \%$ threshold.

Our results highlight that size has a positive influence (at the 5\% threshold when using the Marris) on the performance. Other results are positive but not significant. The influence of security turnover rate is positive and statistically significant (in book or in market value). This result is in line with those of Titman and Wesels (1988). Indeed, these authors show that an considerable volume of transaction shows the discipline of the financial market. It is a means of putting pressure on management to act in accordance with the interests of investors. In addition, the weak security turnover rate for firms located in Unit 4 had a negative (and statistically significant) influence on performance (at the $1 \%$ threshold when using market value to calculate performance). 
Leverage, in book value or in market value, had a negative influence on performance but we noted no statistically significant result. The influence was negative and statistically significant for firms located in Units 3 and 4, in particular for indicators of financial profitability (respectively -0.055 and -0.297 at the $1 \%$ threshold for ROE and Marris). The negative influence of leverage was less significant for economic profitability. So, for the firms located in unit 4 , the coefficients are -0.0138 and -0.137 and are statistically significant at $10 \%$ and $5 \%$ thresholds. These results are consistent with those of Opler and Titman (1994) noting a negative and significant relation between leverage and performance, but our results are not consistent with Jensen's "free cash flow hypothesis" (1986). Leverage and financial distress in particular, have a negative impact on performance.

\section{Conclusion}

Our objective, in this paper, was to understand better the relationship between ownership structure and performance.

The contributions of this article are both economic and methodological.

With regards to the methodological aspect, this work illustrates the utility of SOM. The strong points of these methods are as follows: in particular, they enable analysis of data which are not distributed normally, and allow to determine links between variables that are non-linear. The Kohonen algorithm allows individuals within homogeneous groups to be grouped.

Three main economic results appear.

Firstly, our results suggest on a sample of 199 French firms that the relation between ownership structure and performance is non-linear. Our results are in agreement with the findings of Morck et al. (1988) and of Short and Keasey (1999).

Secondly, our investigations lead us to observe that the external discipline variable (that is the leverage and the security turnover rate) partly explain the performance. Although the leverage negatively influences the performance (Opler and Titman, 1994), on the other hand, the security turnover rate has a beneficial impact on the performance (Charreaux, 1997).

Thirdly, although the organisational variables (Charreaux, 1997) do not have a significant impact on corporate performance, on the other hand, size can explain differences between corporate performances (in market value - Marris -).

These results have numerous limits and lead us to question several points. The first is the measurement of ownership structure. The percentage (held by managers or the Board of Directors) is probably different from the percentage of voting rights. Unfortunately, we know no French database with this accurate information. The second important point in the ownership structure is the presence of institutional investors among shareholders. These shareholders can force managers to create value (Agrawal and Mandelker, 1992; Smith, 1996). 


\section{Appendix 1}

\section{A1.1. Performance variables}

Descriptive statistics.

\begin{tabular}{|l|r|r|c|c|}
\hline & \multicolumn{1}{|c|}{ ROI96 } & \multicolumn{1}{c|}{ ROE96 } & TOBIN'S Q96 & MARRIS96 \\
\hline Mean & 0.040 & -0.010 & 1.203 & 1.988 \\
\hline Median & 0.046 & 0.078 & 1.004 & 1.381 \\
\hline SE of mean & 0.003 & 0.037 & 0.041 & 0.217 \\
\hline Minimum & -0.270 & -6.620 & 0.530 & 0.240 \\
\hline Maximum & 0.170 & 0.230 & 3.640 & 40.250 \\
\hline Kurtosis & 12.545 & 128.974 & 4.624 & 121.174 \\
\hline Skewness & -2.394 & -10.510 & 2.098 & 9.961 \\
\hline
\end{tabular}

Kolmogorov test. ${ }^{30}$

\begin{tabular}{|l|c|c|c|c|}
\hline & ROI96 & ROE96 & TOBIN'SQ96 & MARRIS96 \\
\hline Number of observations & 200 & 200 & 200 & 200 \\
\hline Statistic Z & 2.308 & 4.564 & 2.679 & 4.079 \\
\hline Sig. & 0.000 & 0.000 & 0.000 & 0.000 \\
\hline
\end{tabular}

\section{A1.2. Ownership variables}

Descriptive statistics.

\begin{tabular}{|l|c|}
\hline & $\%$ BOD1995 \\
\hline Mean & 53.126 \\
\hline Median & 55.000 \\
\hline SE of mean & 1.585 \\
\hline Minimum & 1.900 \\
\hline Maximum & 97.500 \\
\hline Kurtosis & -0.233 \\
\hline Skewness & -0.354 \\
\hline
\end{tabular}

${ }^{30}$ Kolmogorov is a non-parametric test. The Kolmogorov statistic measures deviation between the $\mathrm{F}_{n}^{*}$ function and the $\mathrm{F}(x)$ function We know that $D_{n}=\sup \left|F_{n}^{*}(x)-F(x)\right|$ is as follows:

$P\left(\sqrt{n} D_{n}<y\right) \rightarrow \sum_{-\infty}^{+\infty}(-1)^{k} \exp \left(2 k^{2} y^{2}\right)=K(y)$. The $\mathrm{K}(y)$ function allows us to test hypothesis. 
Kolmogorov test.

\begin{tabular}{|l|c|}
\hline & $\%$ BOD1995 \\
\hline Number of observations & 172 \\
\hline Statistic $Z$ & 1.631 \\
\hline Sig. & 0.010 \\
\hline
\end{tabular}

\section{Appendix 2: Results of Multiple Component Analysis}

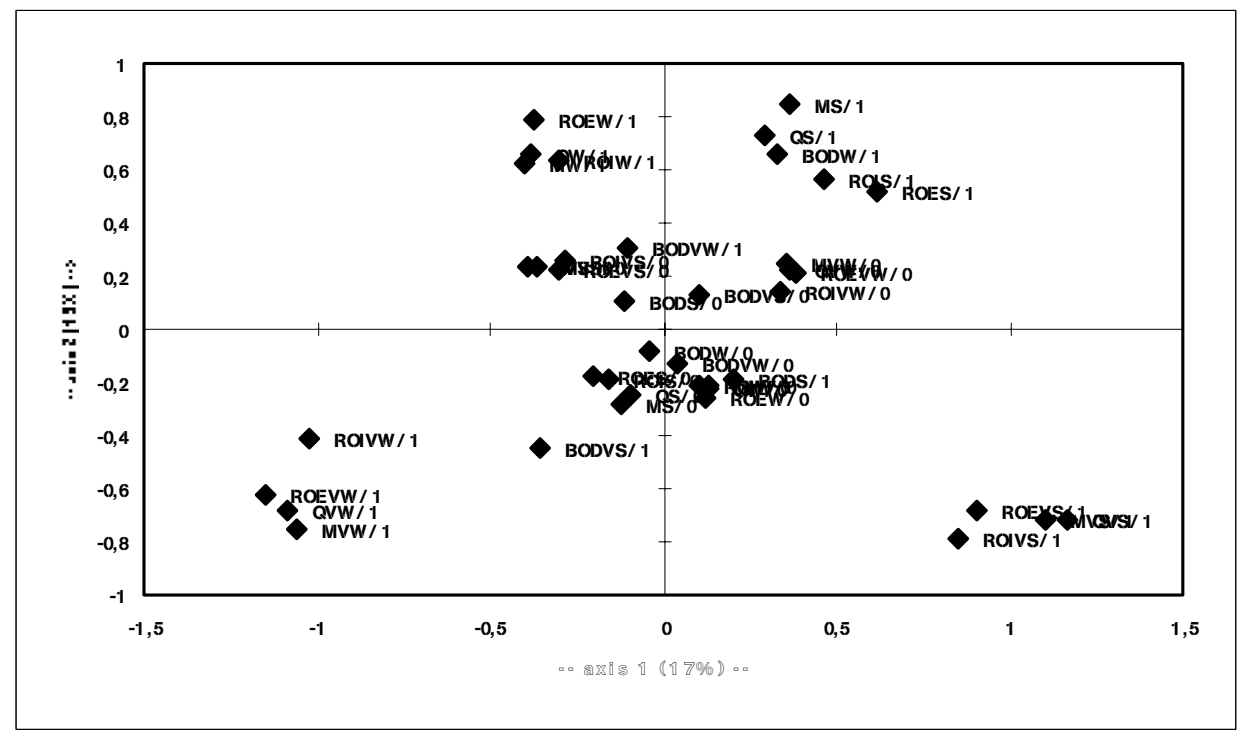

Relationship between the percentage of shares held by the Board of Directors and performance.

The results are not satisfactory. One can observe that the first two axes can respectively explain only $30 \%$ of inertia. 


\section{Appendix 3}

Descriptive statistics of performance and ownership variables for each group.

\begin{tabular}{|c|c|c|c|c|c|}
\hline & ROI & ROE & Q & MARRIS & BOD (in \%) \\
\hline$N$ & 36 & 36 & 36 & 36 & 36 \\
\hline Mean & 0.07 & 0.09 & 1.88 & 4.18 & 48.12 \\
\hline Median & 0.08 & 0.14 & 1.74 & 2.86 & 53.50 \\
\hline$N$ & 70 & 70 & 70 & 70 & 70 \\
\hline Mean & 0.05 & -0.02 & 1.21 & 2.01 & 45.60 \\
\hline Median & 0.05 & 0.10 & 1.13 & 1.74 & 50.35 \\
\hline$N$ & 59 & 59 & 59 & 59 & 59 \\
\hline Mean & 0.03 & -0.01 & 1.03 & 1.39 & 41.80 \\
\hline Median & 0.04 & 0.06 & 0.93 & 1.27 & 49.73 \\
\hline$N$ & 34 & 34 & 34 & 34 & 34 \\
\hline Mean & 0.01 & -0.10 & 0.78 & 0.69 & 49.93 \\
\hline Median & 0.02 & -0.02 & 0.81 & 0.68 & 55.00 \\
\hline
\end{tabular}

$N=$ Number of observations.

\section{References}

Agrawal A., Mandelker G. (1992) Shark repellents and the role of institutional investors in Corporate Governance, Managerial and decisions economics 13, pp. 15-22.

Berle A., Means G. (1932) The Modern Corporation and Private Property. Mac Millan, New York, $2^{\mathrm{e}}$ éd. : 1956.

Blayo F., Demartines P. (1991) Data analysis: How to compare Kohonen Neural Networks to other techniques. In: Proceedings of IWANN'91, Lectures Notes in Computer Science, Springer-Verlag, Berlin, pp. 469-476.

Charreaux G. (1991) Structure de propriété, relation d'agence et performance financière, Revue Économique 3, pp. 521-553.

Charreaux G. (1997) Le gouvernement des entreprises : Corporate Governance, théories et faits. Economica, ouvrage collectif, Paris, $540 \mathrm{p}$.

Cole R.A., Mehran H. (1998) The effet of changes in ownership structure on performance: Evidence from the thrift industry, Journal of Financial Economics 50, pp. 291-317.

Cottrell M., Fort J.C., Pagès G. (1987) Étude d'un algorithme d'auto-organisation, Annales de l'Institut Henri Poincaré 23, pp. 1-20.

Cottrell M., Fort J.C., Pagès G. (1994) Two or three things that we know about the Kohonen Algorithm. In: Proceedings of ESANN, pp. 235-244.

Cottrell M., Fort J.C., Pagès G. (1998) Theoretical aspects of the SOM Algorithm, NeuroComputing 21, pp. 119-138. 
Cottrell M., Letremy P., Roy E. (1993) Analysing a contingency table with Kohonen Maps: A Factorial correspondence analysis. In: Proceedings of IWANN'93, pp. 305-311.

Demsetz H. (1983) The structure of ownership and the theory of the firm, Journal of Law and Economics 26, pp. 375-390.

Demsetz H., Lehn K. (1985) The structure of corporate ownership: Causes and consequences, Journal of Political Economy 93(6), pp. 1155-1177.

Denis D.J., Denis D.K., Sarin A. (1994) Ownership structure and top management turnover, Working paper, Virginia Polytechnic Institute and State University, Pamplin College of Business.

Eisenhart K., Bourgeois L. (1988) Politics of strategic decision making in high-velocity environments: Toward a midrange theory, Academy Management Journal 31, pp. 737-770.

Fama E.F. (1980) Agency problem and the theory of the firm, Journal of Political Economy 88(2), pp. 288-307.

Fort J.C., Pagès G. (1995) About Kohonen algorithm: Strong or weak self organization, Neural Networks.

Gaubert P., Cottrell M., (1999) A dynamic analysis of segmented labor market, Fuzzy Economic Review 2.

Gaubert P., Cottrell M., (2000) Classification of recurring unemployed workers and unemployment exits, European Journal of Economic and Social Systems 14, pp. 53-68.

Gujarati D.N. (1995) Basic Econometrics. 3rd ed., Mc Graw Hill Book Co, Singapore.

Hirigoyen G., Caby J. (1997) La création de valeur de l'entreprise. Economica, Paris.

Howe K.M., He J., Kao G.W. (1992) One-time cash flow announcements and free cash theory: Share repurchases and special dividends, Journal of Finance 47, pp. 1963-1975.

Ibbou S. (1998) Classification, analyse des correspondances et méthodes neuronales. Thèse, Université de Paris I-Panthéon Sorbonne, UFR de Mathématiques et d'Informatique.

Ibbou S., Cottrell M., (1995) Multiple correspondence analysis of a crosstabulation matrix using the Kohonen algorithm. In: Verleysen (Ed.), Proceedings of ESANN, De facto, Bruxelles, pp. 27-32

Jensen M.C. (1986) Agency costs of free cash flow, corporate finance, and takeovers, American Economic Review 76, pp. 323-329.

Jensen M.C. (1993) The modern industrial revolution, exit the failure of internal control systems, Journal of Finance 48, pp. 831-880.

Jensen M.C., Meckling W.H. (1976) Theory of the firm: Managerial behavior, agency costs and ownership structure, Journal of Financial Economics 3, pp. 305-360.

John K., Ofek E. (1995) Asset Sales and Increase in Focus, Journal of Financial Economics 37, pp. 105-126.

Kohonen T. (1982) Self-organized formation of topologically correct feature maps, Biological Cyberbetics 43, $59 \mathrm{p}$.

Kohonen T. (1995) Self-Organizing Maps. Springer Series in Information Sciences, SpringerVerlag, Berlin.

Kole S.R. (1995) Measuring managerial equity ownership: A comparison of sources of ownership data, Journal of Corporate Finance 1, pp. 413-435.

Kosnik R. (1990) Effects on board demography and directors' incentives on corporate greenmail decisions, Academy Management Journal 33, pp. 129-151.

Lang L., Litzenberger R.H. (1989) Dividend announcement, cash flow signalling $v s$. cash flow hypothesis, Journal of Financial Economics 24, pp. 181-191.

Mace L. (1986) Directors, Myth and Reality. Harvard Business School Press, Boston. 
McConnell J.J., Servaes H. (1990) Additional evidence on equity ownership and corporate value, Journal of Financial Economics 27, pp. 595-612.

McConnell J.J., H. Servaes H. (1995) Equity ownership and the two faces of debt, Journal of Financial Economics 39, pp. 131-157.

Morck R., Shleifer A., Vishny R.W. (1988) Management Ownership and Market Valuation, Journal of Financial Economics 20, pp. 293-315.

Morin. F. (1974) La structure financière du capitalisme français. Éditions Calmann-Levy, Paris

Nijoukou C. (1994) Relations d'agence et structure financière des entreprises : théorie et tests empiriques. Thèse de doctorat, Université de Grenoble.

Noronha G.M., Shome D.K., Morgan G.E. (1996) The monitoring rationale for dividends and the interaction of capital structure and dividend decisions, Journal of Banking Finance 20, pp. 349-454.

Oja E. (1982) A simplified neuron model as a principal component analyser, Journal of Mathematical Biology 15, pp. 267-273.

Opler T., Titman S. (1994) Financial distress and corporate performance, Journal of Finance 49, pp. 1015-1040.

Patton A., Baker J. (1987) Why do not directors rock the board?, Harvard Business Review 65, pp. 10-12.

Pigé B. (1996) La probabilité de rotation des Pdg : une mesure de pouvoir de révocation du conseil d'administration, Revue d'économie politique 106, p. 889-912.

Platt H.D., Platt M.B. (1994) Business cycle. Effects on state corporate failure rates, Journal of Economic Business 46, pp. 113-127.

Ritter H., Schulten K. (1988) Convergence properties of Kohonen's topology conserving maps: Fluctuations, stability and dimension selection, Biological Cybernetics 60, pp. 59-71.

Robins H., Monro H. (1951) A stochastic approximation method, Annales de Mathématiques et de Statistiques 22, pp. 400-407.

Saporta G. (1990) Probabilités, analyse de données et statistique. Éditions Technip, Paris.

Shleifer A., Vishny R.W. (1989) Managerial entrechment: The case of manager-specific investments, Journal of Financial Economics 25, 1990, pp. 123-139.

Short H., Keasey K. (1999) Managerial ownership and the performance of firms: Evidence from the UK, Journal of Corporate Finance 5, pp. 79-101.

Smith M.P. (1996) Shareholders activism by institutional investors: Evidence from CalPERS, Journal of Finance 51, pp. 227-252.

Titman S., Wessels R. (1988) The determinants of capital structure choice, Journal of Finance 43, pp 1-19.

Vancil R. (1987) Passing the baton: Managing the process of CEO succession. Harvard Business School Press, Boston.

Volle M. (1981) Analyse des données. Economica, $2^{\mathrm{e}}$ édition, Paris.

Waldo C. (1985) Boards of Directors: Their Changing Roles, Structure and Information Needs. Quorum, New York.

Wonnacott T.H., Wonnacott R.J. (1991) Statistique. Economica, 4 éd., Paris. 